\title{
Study on "Ego" in Kafka on the Shore
}

\author{
Wanlong Zhu \\ Dalian Neusoft Institute of Information \\ Dalian, China 116023
}

\begin{abstract}
Haruki Murakami's literary works mostly focus on the themes such as magic, prophecy, life and death, good and evil. And the novel "Kafka on the Shore" embodies this feature. The struggle between ego and power is hidden in the work. The protagonist struggles in the good and evil of human nature outlines the longing for power and ugly nature in the illusion and real world. The text is full of metaphors of human nature and critique of power. It has rich research value. The novel has both the classic Murakami style double-line article structure and the borrowing of ancient Greek mythology story Oedipus. Through the magical storyline, metaphorical methods are used to describe the goodness and evil of human nature. First of all, through the analysis and comparison of the protagonist, the paper analyzes the difference between good and evil in the novel. Secondly, by comparing and contrasting the changes of "ego" in life and death, illusion and reality, the relationship between "ego" and power is clarified. Finally, the author finds the criteria for defining the good and evil of ego, power, and human nature in "Kafka on the Shore".
\end{abstract}

Keywords-prophecy; ego and power; good and evil of human nature

\section{INTRODUCTION}

The novel "Kafka on the Shore" takes the cursed young Kafka Tamura as the main clue. Also, it takes "Satoshi Nakada" who lost half his ego in the strange coma as the supplement clue. With the double-line writing techniques, it shows the readers a fantastic story about life and death, good and evil. Viewing the structure of "Kafka on the Shore", it has two seemingly parallel development clues. And odd chapters focus on realism. That is the growth experience of Kafka. Even-numbered chapters focus on magic. And it is about the struggle between "ego" and power. Eventually through the interweaving and collision of the two clues, it would construct a fantastic and strange story. Starting from two main lines, this article will demonstrate and analyze the difference between life and death and the good and evil. Firstly, through the adventures of Kafka's trip, it is mainly about the encounter with his mother Saeki at the Memorial Library of Jia Village. The author discusses the difference between life and death in his works. Secondly, the author analyzes the demarcation between good and evil in his works from the struggle of "ego" and power between Satoshi Nakada and Kafka's father, Koichi Tamura.

\section{ANALYSIS AND COMPARISON OF THE PROTAGONISTS}

\section{A. Kafka Tamura (Odd Chapter)}

As the first protagonist of the novel Kafka Tamura appeared in odd chapters, his mother and sister left Kafka Tamura in his teenagers. And he followed their father to live. The discord between father and son is clear. And he also carries the father's curse. Kafka is silent since childhood. He hopes to be loved. However, he does not have father's affection. This makes Kafka miss mother and sister. In this context, in order to protect himself, Kafka built layers of "protection network" in the heart and created a teenager who named "crow". That is to say, the protagonist Kafka is the 15 -year-old teenager of dual personality.

From the conversation between the two men at the beginning of Chapter 1, we can see that Kafka rarely speaks, but nods or blushes. And he admits that he is a person who blushes immediately. It is inferred that it belongs to physical domination the body in the dual personality. Also, it is in the lower position of the relationship between Kafka and his fission. And "the teenager called crow" belongs to spiritual leadership. Also, it is in the upper position of the relationship between Kafka and his fission. Kafka always obeys the willingness of "the boy called crow". And he would show his trust and respect in the dialogue. This shows that "the boy called crow" is not a trespass to the inner world of Kafka. It is a spiritual pillar created by Kafka's own consciousness.

Kafka is a careful and shy person. Kafka's determination to be strong can be felt in the details of his preparations to run away from home. He had meticulous planning. With the persistence of physical exercise, he would do expression exercises on front of the mirror every day. And then, people wouldn't see the age and ideas from the face, and so on. The readers can feel his unease, pain and loneliness. An ordinary 15 -year-old boy is in the adolescence period. He should be carefree to live in the happiness. However, Kafka must refrain from his feelings and build a "protective wall" in his heart. No one is allowed to enter. And he will never show his inner world to the outside world. Kafka's running away from home can be said to look for the love. And he wants to be loved in his heart. It is understandable that he wants to be loved as well as to love other people. With his memory of his mother and sister, Kafka opened his own journey.

Kafka encountered Oshima, the curator of the Memorial Library. The gears of fate began to run. And the prophecies and curses carried on Kafka began to be confirmed. In the 
guest room of the Memorial Library, Kafka sees Saeki who is regarded as his mother. And he is madly obsessed with his girlish mother. However, 15-year-old Saeki has a dead lover in the heart. And Kafka has no place in Saeki's heart. And then, Kafka was in chaos. It is unable to extricate himself from the whirlpool of time. Kafka experienced the disappointment. Then, he passed through the forest. He passed through the entrance guarded by two Japanese soldiers. And then, he entered into "that world". In that world, Kafka lost his "ego" completely. He looks like a walking dead body. Finally, he bravely came out of the whirlpool of time with the persuasion of his mother, Saeki. He chose to face life squarely, and came back to the reality to greet the new life. Life is a kind of difficulty. The experienced things may be a kind of pain. However, if we don't have experienced those things, or we erased all the past memories, such a simple life would have no difference from death. And then, when we facing the fate as described in the book, people often have nowhere to escape. On the contrary, if you dare to step into it and face it firmly, you are no longer you when you step out of it. And people can get the ultimate redemption. Thus, it would accomplish self-transcendence and self-remolding. Kafka encountered the guide who helped him in the process of self-exile. And he was also guided by the gods of nature. He obtained spiritual growth with the help of the outside world and his understanding of life.

At the end of the work, Kafka sits on the bus home with the painting "Kafka on the Shore". The talks to "the boy called crow" would suggest that the two will become one. After living and dying, Kafka finally completes the redemption and reshaping of "ego".

\section{B. Satoshi Nakada (Even-numbered Chapter)}

Even-numbered chapters revolve around elderly people Satoshi Nakada with mental retardation. As a child, Satoshi Nakada lost his ability to read and write after bizarre "collective coma". After waking up, Satoshi Nakada had only half a shadow. That is to say, he had lost half his "ego". And he had acquired the ability to communicate with cats. After growing up, he would look for lost cats for the neighborhood. With this, he has some reputation. Living by government subsidies and the bounty of looking for cats, life is not rich but carefree.

According to the recollection of the female teacher in the "collective coma incident", the female teacher fused with her husband, who had died in the front line at the night before the incident. On the next morning, when she took her pupils up the mountain to collect supplies, the female teacher suddenly had a period due to her "fusion" with her husband. However, the handkerchief of emergency treatment was picked up by Satoshi Nakada. And he sent back to the female teacher. This made the female teacher feel ashamed. She hit Satoshi Nakada and made him unconscious. And then, the "collective coma" took place. Connected with the plot, we can have the speculation. After the opening of the entrance of that world opened on the eve of the event, the soul of the husband of the female teacher entered the dream of the female teacher. And on the next day, the stone entrance was not closed. And the children and the female teacher happened to pass by and were involved in the "world". And the "collective coma" happened. The children are in a coma. However, adult female teachers have no symptoms. Perhaps children's "ego" is incomplete. And then, they will be affected. It takes a while to turn it off, and it can only be seen by the incomplete "ego".

After the above inference, all the children except Satoshi Nakada immediately woke up after the "collective coma incident". Satoshi Nakada was sent back to Tokyo for treatment. It can be explained that Satoshi Nakada entered the "world" after being beaten into a coma. And half of the "ego" remained in it without returning to the body. However, this body of Satoshi Nakada became the most suitable carrier to enter "that world", which was concerned by Koichi Tamura. With the introduction of Kafka's father Koichi Tamura, Satoshi Nakada witnessed death of the cat. His father took the heart and soul of the cat. What his father did is to stimulate Satoshi Nakada to kill himself. Only by forcing Satoshi Nakada to kill himself, who has lost half of his ego, Koichi Tamura can enter the body of Satoshi Nakada and wait for the entrance to the "world" to be opened again. More importantly, Satoshi Nakada has lost half his ego. Kafka in his dream was able to plunge into Nakada from imaginary space and kill his father. This fulfilled the curse. And it opened the wheel of Kafka's destiny. And then, he met Saeki in the whirlpool of time, found and entered the "world", and opened the entrance. At that time, Satoshi Nakada could break free from Koichi Tamura's body and enter the imaginary space as a dead person. He would obtain the power to rule the world.

After killing Koichi Tamura, Satoshi Nakada turned himself in to the police. However, he didn't get much attention. He chose to leave the city and embarked on his journey with a young man named Hoshino. During the journey, Satoshi Nakada found that he had lost the ability to talk to the cat. However, he could make the sky drop all kinds of small fish. It can be understood that the "magic flute" made with the soul of the cat has brought about changes after entering Satoshi Nakada's body.

In the unseen world, Satoshi Nakada arrived at the Memorial Library in Shikoku and met Saeki there. They chatted like old friends about each other's painful memories and burdened missions. So far, the odd and even-numbered chapters of parallel development would converge in the whole work. The story ushered in the end. Miss Saeki chose to disappear from the real world after asking Satoshi Nakada to burn down her memories. And Satoshi Nakada went to sleep after burning down Miss Saeki's memories. He waited for the entrance to be opened again.

\section{Comparison of "Ego"}

In "Kafka on the Shore", Kafka Tamura is a 15-year-old boy, a "raven boy" and an old man who named Satoshi Nakada. He is the one of "ego", "inner ego" and "super ego". The book introduces the concept of "half shadow". That is, only to find the other half of the shadow would be a complete person. That is to find their own lost half of the "ego". They have their own part of human nature such as 
sensibility, rationality and society. The process of finding the shadow is the process of improving themselves. In the plot of killing Kafka's father Koichi Tamura across time and space, Kafka completed the transition from self-participation "Juvenile of Ravens" to Satoshi Nakada who had lost selfconsciousness with extreme stimulation. With the help of Satoshi Nakada who only has "half shadow", he killed his father. It fulfills the prophecy of Kafka's teenagers and begins the redemption and remolding of "ego".

Satoshi Nakada and Miss Saeki chose to return back. They left the real world that does not belong to them. And then, they return to the world that inner ego is there. With the burned-out memories, Miss Saeki ended up wandering in the whirlpool of time. When Satoshi Nakada opened the entrance to that world, she and Hoshino worked together to prevent the imaginative Koichi Tamura from entering the entrance. Eventually, before Kafka returned to reality and the entrance was closed, she and the young man named "Crow" succeeded in destroying the delusion of attempting to rule the world.

The changes of "ego" in "Kafka on the Shore" have been embodied in Hoshino. From his first encounter with Satoshi Nakada to saving the world jointly, Hoshino experienced the growth and transformation of "ego". As one of the characters who are close to "evil" in his works, there was no distinction between "good and evil" in Hoshino's mind. With the curiosity, he went along with Satoshi Nakada. As he talked with Satoshi Nakada, he gradually changed his perspective from being attracted to understanding. Hoshino appeared on the plot of "good and evil" character. He could have accepted the terms of Koichi Tamura and helped him reach the entrance to the "world". However, in the end, Hoshino rejected the terms of Koichi Tamura. He chose to join Satoshi Nakada to prevent Koichi Tamura from destroying the world. And he stood on the side of "good". This can also be regarded as the repair and improvement of "ego".

\section{CONCLUSION}

Kafka Tamura has the shadow of Oedipus in ancient Greek mythology. Life always seems to be controlled by mysterious and blind force. And what has happened will work according to the will of heaven. Oedipus was at last unable to escape from his destiny. He was bound to his destiny. Whether saving others or harming others, he could only walk towards the abyss of his destiny step by step. In the end, he just could obey his destiny. In Kafka's story, he does not simply choose to wait. On the contrary, he is moving towards the direction of the prophecy. Later, when he knew that Saeki might be his own mother, he still accepted the love with her. Later, in the dream, he fell in love with his identified sister cherry. The plot is not simply to show that destiny is to run according to the prophecy. It is to show that the author endows Kafka with the attitude of challenging destiny. Kafka knew his destiny from the beginning. He loved and hated his mother. And he would invade his sister and mother. On the one hand, it is due to the destiny. On the other hand, he was using his destiny to vent his hatred. It reflects the tossing and turning between life and death, reality and illusion.
"Kafka on the Shore" could be divided into body schema and power pattern. Power tries to control the body. And the non-normal body is the representative in the works. It is trying to show us a way to the whole body without confronting the power. In "Kafka on the Shore", it is to look for the complete "ego" and depict the human's growing experience metaphorically. It should experience hardship and self-reflection. And they would reach the other side of life. It is a literary work that can arouse the readers' sympathy. As the translator of the novel, Mr. Lin Shaohua says, "Kafka on the Shore" proves the power of literature. In other words, it proves the power to redeem the soul.

\section{REFERENCES}

[1] Haruki Murakami. Translated by Lin Shaohua. Kafka on the Shore [M]. Shanghai Translation Publishing House, 2007 (7). 村上春树, 林少华译.海边的卡夫卡[M].上海译文出版社，2007（7）

[2] Cui Xiang. The destiny and salvation in "Kafka on the Shore" [J]. Yalu River (2nd edition), 2015 (2). 崔香. 论《海边的卡夫卡》中的 宿命与救赎 [J].鸭绿江(下半月版), 2015 (2)

[3] Chen Jing. The heterogeneity of Haruki Murakami's novelsAnalysis on Kafka on the Shore [J]. Changchun Jiaoyu Xueyuan, 2014(5). 陈静.村上春树小说的异质特色一一解读《海边的卡夫 卡》[J].长春教育学院学报, 2014(5)

[4] Xu Heng. Haruki Murakami's Kafka on the Shore [J]. Literature Education (1st edition), 2014 (09). 徐桁. 读村上春树《海边的卡夫 卡》[J].文学教育(上), 2014(09) 